\title{
Literacy practices, texts, and talk around texts: english language teaching developments in colombia
}

Silvia Valencia Giraldo

\begin{abstract}
This paper seeks to provide a window into the complexity of classroom interaction in English language classes in public secondary schools in Colombia. It will show the relationship between what goes on in public schools and classrooms, the wider policy context, and recent reforms. Through a detailed analysis of data collected in two schools and the interaction that takes place between the two teachers and their students around and about texts, this artcicle provides insights into the specific nature of the literacy practices, the texts used, and the particular ways in which the teachers and learners made sense of these texts. It examines how the students are learning to read in English in these classes, and what the teachers understand by 'doing reading' and 'reading comprehension'.
\end{abstract}

Key words: classroom interaction, textbooks, texts, literacy practices, ELT, talk around texts, globalization, policy.

\section{Resumen}

Este artículo muestra la complejidad de la interacción en el aula de clase de inglés en dos colegios públicos de educación básica secundaria en Armenia, Colombia y su relación con las políticas educativas y las recientes reformas a nivel nacional. A partir de una detallada descripción de la interacción entre profesor(es) y estudiantes se analizan las practicas pedagógicas y los textos utilizados. Igualmente se examinan los textos empleados y como el profesor y sus estudiantes encuentran el significado del texto, así como la forma como en este contexto los estudiantes están aprendiendo a leer y qué se entiende por comprensión de lectura.

Palabras claves: textos, interacción en el aula de clase de inglés, prácticas de lecto-escritura, Enseñanza aprendizaje del inglés, el habla alrededor del texto.

\footnotetext{
* Received: 15-05-06 / Accepted: 15-08-06
} 


\section{Introduction}

In the last decade there has been a marked increase in the commodification of English as an economic asset and a representation of English learning as a necessary requirement for modern living, not only for students, but also for professionals, and the population in general. Colombia has not been able to escape the impact of globalization. Especially since the late 1980s, the effects of globalization have become more evident. There is a dominant discourse about investing in English, and many people associate it with prosperity, a prosperity that many assume will be available to large sectors of the population. However, the reality is that merely learning English in the context of public education will not guarantee students a better future. Considering that public schools students spend only a few weekly hours dedicated to 'learning' the language in conditions that are, in most cases, not conducive to language learning, the proficiency that they achieve in English is unlikely to provide them with access to job opportunities.

This article stems from the awareness of the scope or the need for teacher education and support in the field of English Language Teaching (ELT) in Quindío and the need to provide teachers in public schools with opportunities to reflect on their immediate teaching /learning context and on the wider policy context. This paper focuses on the teaching and learning of English as a subject in the secondary school curriculum of two public schools in Quindío. It draws on research carried out for my doctoral studies, a case study of two teachers in two secondary public schools in Armenia, two English lessons in each school. My aim in this study has been to construct a critical analysis of the relationship between language education policy and practice. I have intended to build a deeper explanatory account of the interactional practices of the English lessons in this study than would have been possible if the focus had remained on face-to-face interactions.

The core of the study is based on the tradition of research on interaction in the language classroom (Allwright, 1997). It draws on descriptive and analytical frameworks developed in applied linguistics and educational research, primarily (1) the ethnography of communication; (2) classroom discourse analysis; (3) contemporary approaches to the study of talk around texts in the classroom; and (4) recent research on bilingual discourse and codeswitching in educational contexts. The study pays particular attention to the literacy practices, the texts, and the talk around texts in these classes, the nature of the texts used in the two classrooms and the uses of texts. The following questions will guide the analysis in this article: 
1. How and to what extent are ELT teachers in public schools influenced by global trends and pressures?

2. How and to what extent are they influenced by language policy developments in the Colombian context?

3. How do they approach the teaching of reading in English? What counts as'doing reading'?

4. How do teachers select, construct and use texts in their classrooms and what insights do these practices provide into the ways in which they are responding to global pressures and local policy conditions?

\section{The research context for this study}

Reading and writing in language classrooms: perspectives from the New Literacy Studies

The tradition of research that has come to be known as the New Literacy Studies (Heath, 1983; Gee, 1990; Street, 1984, 1993; Barton 1994) is based on a sociocultural view of literacy. According to Street (1993) a range of terms refer to the uses of literacy in different social contexts. They are typically used by researchers who are committed to a social view of reading and writing. Two terms, in particular, occur frequently in the New Literacy Studies: 'literacy events' and 'literacy practices'

According to Street, the term 'literacy practices' 'represents an attempt to handle the events and the patterns of activity around literacy, but to link them to something broader of a cultural and social kind' (p. 21). The term echoes the earlier term 'speech event' that came out of the work on the ethnography of communication.

Literacy practices vary with cultural context, as 'literacy' or 'literacy practices' are shaped in particular ways in each context. There are therefore, many different manifestations of literacy, 'rather than a single monolithic and 'autonomous' literacy' (p. 25).

Martin-Jones and Jones (2000) use the plural form of 'literacies' to 'signal a critique of the a-social, a-historical skill/ability understanding of reading and writing associated with ... the 'autonomous' views of literacy' (Martin-Jones and Jones, 2000, p. 4). This term acknowledges the diversity of practices of reading and writing, along with the uses of different genres, styles, and types of 
texts related in different domains of social life. Martin-Jones and Jones also see literacy practices and uses of texts as social practices, that is, "ways of reading and writing and using written texts that are bound up in social processes which locate individual action within social and cultural processes' (p. 5).

These core concepts from the research developed in the New Literacy Studies contributed to the analysis of the literacy practices in the four lessons observed and documented for the two classes in this case study.

\section{The move towards socially oriented research}

In the 1990s calls were made for critical ethnographies in classrooms (Canagarajah, 1993; Norton Pierce, 1995). Norton Pierce (1995) argued for 'classroom-based social research in order to engage the social identities of students in ways that will improve their language learning outside the classroom and help them claim the right to speak' (1995, p. 26). As Auerbach (2000) argued, classrooms need to be seen as both social sites in themselves and as part of the larger social world; they need to be seen as socially located. Together with the social turn in studies of English language pedagogy, the role of teachers has also been questioned, according to Gee (2000, p. 190),

'English teachers can cooperate in their own marginalisation by seeing themselves as 'language teachers' with no connection to social and political issues...like it or not, English teachers stand at the very heart of the most crucial educational, cultural, and political issues of our time'.

These issues will be addressed in connection to the EFL/ELT textbook. It is to this discussion that I now turn to in the following section.

\section{Textbooks}

Textbooks continue to have a predominant role in educational contexts all over the world, as most school practices depend on them. According to Luke et al. (1989) 'the text 'qua text' has remained constant - a fixed locus within the schooling system from which the means and ends of instruction are derived' (as cited by Dendrinos, 1992). The relationship between the text and pedagogical practice is not one of subordination of the textbook to the latter.

Knowledge in schools is constructed via the textbook. It constitutes an 'authorised medium that conveys to pupils legitimate knowledge' (De Castell and Luke, 1987. p. 413-14). It often defines the curriculum content 
and, therefore, the choice of content and methodology. As Dendrinos (1992) argues, the relative importance of the textbook seems also to be connected with the existence of a national curriculum; so the tighter the state control over the educational content and instructional practice, the stronger the reliance on the textbook (1992. p. 25). So, while the textbook does appear to guide classroom-based interactional activities, its authority also derives from sources outside the classroom, including curriculum authorities, local and central government departments concerned with education and multinational publishing companies. However, the issue of 'authority of the textbook' in contexts where textbooks are not readily available, deserves a closer analysis, since in schools, such as the ones in this case study, the authority of the text resides not in the text(book) as such, but in other texts that the teachers create from a range of existing textbooks.

Thus, in different educational contexts across the world, such as these, the textbook or textbook-derived worksheets largely determine the teaching content. The textbook is the main means by which the syllabus is organised. Moreover, students' achievement is assessed according to textbook content. According to Dendrinos (1992, p. 26), even where textbooks are commercially produced 'their selection and prescription are usually responsibilities of...the Ministry of Education or other State agencies and their content determines university entrance examinations'.

In Dendrinos' view, teachers become mediators of textual knowledge in their classrooms. They have an active role selecting, emphasizing, excluding and de-emphasizing particular aspects of the language to be learned (1992, p. 29). Teachers' power to select and produce texts is, however, determined not only by the curriculum and by the limitations of their school, but also by the demands of national policy and the local policy of the schools. Furthermore, the authority of the textbook and of the teacher as mediator is also shaped by the interactional practices emerging in each class.

There are also issues dealing with the origins of texts and with text availability and selection. Dendrinos (1992) points out that teachers may have a limited choice of texts, due to limited prescriptions, authorisations, or screening. In other cases, when they have the right to decide on the selection of texts, they are not provided with appropriate training, information, guidance and facilities; without this kind of support, 'apparent autonomy is effectively impotence' 
(1992, p. 33). The marketing of textbooks by commercial publishers and the cost of books are further external factors that have a bearing on the selection of textbooks. The apparent choice that teachers have is thus restricted by the market and its rules. Dendrinos (1992) makes similar observations about foreign language textbooks. She says:

'it seems that they sell better if they demand no preparation on the part of the teacher or if they have few open-ended items -so that the pupils can always be provided with a 'right' answer; if the activities do not pose intellectual demands for pupils; if the material in the textbook does not address an 'identifiable group of pupils' especially if it is intended for youth pop culture' so that it makes it attractive for its consumers (Dendrinos, 1992, p. 35).

These factors then position the learners and the teacher in particular ways. As Pennycook (1994) notes, publishers do not account for the diverse cultures in the global market. Textbooks produced both in the United States and the United Kingdom are often inappropriate in other contexts (Pennycook, 1994, p. 20). As Ellis (1990, p.13) has remarked, textbooks produced in the West 'remain ethnocentric and give little consideration to other sociocultural contexts'. In addition, Prodromou (1988, p. 76) comments that ELT textbooks are 'stubbornly Anglo-centric' in their content, portraying idealised stereotypes of North American or British middle class people, and assuming a materialistic set of values (Prodromou, 1988, as cited by Pennycook, 1994, p.177).

The monolingual feature of the ELT textbook certainly grants them more authority and power than the teacher. The linguistic background of the learners and the knowledge that locals have of their own culture, their needs and expectations are not accounted for (op.cit). An additional feature of ELT textbooks is not only the methodology promoted, but also the variability in the discourses, genres and visual and verbal texts embodied in them.

Textbook authority and production are determined by several factors, namely, local education and central education departments, curriculum and syllabuses often imposed by national or local policy. In world contexts, such as the one in this case study, 'texts' also depend on the texts that are re-created in worksheets and which are governed by strict general conventions. However, other additional factors play significant roles in the production and distribution of texts, such as multinational companies and publishers and ELT agencies. Teachers are mediators of texts in and through classroom interaction in real 
classroom events, where the students both collude with and resist teacher and textbook authorities.

\section{Elt and policy implementation in colombia}

Although there have been reforms in the field of ELT in Colombia and elsewhere, these have not produced the changes expected. For example, with the 1982 English Syllabus (Programa de Inglés, Ministerio de Educación Nacional, 1982), the Ministry of Education (MEN) intended to overcome the dificulties created not only by the diversity of textbooks teachers were using, but also by the absence of a consistent method across schools. The syllabus was intended to take the first steps towards establishing reading comprehension as the main long term objective in ELT in Colombia. However, many of these innovations have now changed with the introduction of the General Law of Education (Ley General de Educación, MEN, 1994) and the implementation of the PEI (Proyecto Educativo Institucional, (MEN, 1997), the Curricular Guidelines (Lineamientos Curriculares, Ministerio de Educación Nacional, 1999), Attainment Targets (Indicadores de Logros, MEN, 1999), and the most recent intervention, 'La Revolución Educativa' (2000). Yet, the picture is far from clear, as teachers in public schools struggle to accomplish lessons and comply with policy reforms.

\section{The research settings and the data collected}

In order to negotiate site entry in the initial phase of data collection, it was necessary to obtain the informed consent of participants in order to 'avoid problems of data quality and of research ethics... as focal subjects are especially vulnerable'(Erickson, 1990). I had a presentation letter addressed to the heads of the schools, who then introduced me to the coordinators before I finally met the teachers. Access to the classes proved to be a difficult process because in some schools, teachers were apprehensive about my presence; as they feared being evaluated.

The main data for the study consist of four English lessons, two in $10^{\text {th }}$ grade (School A), two hours a week, and two in $8^{\text {th }}$ grade (School B), three hours a week, that were observed and audio-recorded in each school, together with semistructured interviews with the teachers and the schools' coordinators; copies of the worksheets and sections of textbooks used by the teachers in the lessons observed and recorded and school policy documents relating to their 
specific curriculum development work, Proyecto Educativo Institucional (PEI), Institutional Education Project (Ministerio de Educación Nacional, 1997).

Two areas had been selected for School A's PEI: Science, Mathematics and Computers. A project on Environmental Education was already up and running when I started the observations, this explains the topics and the practical activities at the end of the worksheets in this class, as I will show further on (see Appendix B). In School B, the areas of emphases in the schools's PEI were (1) Management of Natural Resources, and (2) Sports Promotion and Community Rrecreation.

The two teachers who participated in this study were both experienced teachers who had been teaching for more than twenty years and had a degree in Modern Languages. Although they both had been assigned English courses, this was not, and still is not the usual procedure in local public schools. A considerable number of them also have postgraduate degrees in different areas (not necessarily the area they are currently working in). Their additional expertise includes Sex Education, Spanish-American literature, and the application of Information Technology to Education, among others. A number of teachers were doing postgraduate work in areas different to ELT at the time I was collecting the data for this case study.

It has been the policy of the Ministry of Education and the local education authorities that teachers should have the option of taking courses in an area of their preference so that they can be awarded points that can be counted towards a salary increase. In order to comply with the requirements of the Ministry of Education and because of the need to upgrade their practice, and at the same time to increase their salaries, teachers have done postgraduate work, in areas not directly related to their area of specialisation. The teachers in this study, and others I talked to were concerned about their proficiency in English. As they said, there were few opportunities to speak the language. The absence of continuing education or postgraduate courses in the region has forced many teachers to opt for the areas mentioned above. This situation is changing at the moment, since a reform is underway. When this reform is implemented teachers will have to join research projects in their areas, at a certified (accredited) university ${ }^{1}$.

1 Although this is part of the policy reforms introduced by Law 115, in practice it has not been implemented, as teacher research in public universities is not significant and accreditation processes are slow. 
From my interviews with the teachers I learned that these teachers (from now on Teacher A and Teacher B), like many others in the schools I visited and the ones where I carried out my study were not pleased with their work and the way their classes evolved. They expressed their dissatisfaction and frustration with the general attitude of the students towards school and homework. Especially one of the teachers, complained that the students show apathy towards work and lack interest towards all subjects in general. In both schools, there was a general pessimism among teachers about the students' achievements in English, due mainly to the generalized apathy of the students and the few hours devoted to the subject in the school curriculum.

After having finished collecting the data in both schools, I met with the academic coordinators of both schools to discuss the policy regarding grading systems, methodology, and discipline observing the strictest ethics of research. In the final phase of fieldwork I took the data back to the participants. In order to ensure research credibility in qualitative research, interpretation must be 'credible to those being researched' (Davies, 1992). Individual meetings with both teachers, and informal meetings with students were then held on several occasions. Teachers' reflections on the data analyzed corroborated the hypotheses resulting from the analysis of the data.

The majority of the students in these two schools shared the same working class background. In most cases, both parents worked, mostly as agricultural workers, janitors, watchmen, maids, in child-care or as workers in the local coffee mills ${ }^{2}$. A considerable number of students still lived in temporary housing provided by the local authorities after the earthquake that has hit the city in 1999. It was also common to find homes where the mother was the head of the family. A nation-wide programme led by the government, gave mothers the opportunity to earn some money in community nurseries provided by women in their own homes (hence the child care workers mentioned above). In many households, there was more than one family living together under the same roof. Due to the critical economic situation, it was common to find students who attend school without having eaten a meal, and/or additionally without money for a snack. In order to help remedy this situation, teachers very often paid for the students' snacks, or as the teacher in Colegio Departamental

2 Coffee mills were one of the most important sources of employment in the city, especially for women; however, with the fall of coffee prices in international markets, the coffee industry is gradually disappearing and as a result, unemployment has increased considerably. 
pointed out to me, they bought notebooks and dictionaries for students who did not have them.

\section{Literacy practices and teachers' ideas about reading}

In all the schools I visited and those in which I did my observations, there seemed to be a consensus about reading comprehension as the skill that should be emphasized in English courses in the schools. Academic coordinators were also emphatic about the role of reading. Yet, as I will show, the picture about the way reading is actually done in the classrooms in this study is far from clear. Moreover, the teachers' and the coordinators' ideas of what counts as reading and how it is to be carried out in English lessons is not consistent with the reality of the classroom and school context.

The variety of topics in the worksheets reflected the need to meet the policy requirements of the PEI for each school, that is, the established areas of curricular emphasis in the schools. The worksheet content also reflected the teachers' traditional concern with grammar as a basic tool to read and comprehend written English. In addition, there were other factors constraining the use of the texts in these classes, factors that undermined the teachers' aims and agendas.

\section{The texts}

The texts in these classes came from a range of sources, mostly from commercially produced ELT textbooks published by multinational publishing companies. Sometimes, texts were also extracted from abridged reading series, from magazines and from the web.

\section{Selection of texts and design of worksheets}

Although there were no definite criteria for selecting texts, most texts were chosen according to their length and because of the grammar points covered. Teachers continuously looked for short or brief passages or dialogues with simple language and structures, suitable for work on particular grammar content. Although the majority of public schools do not require students to buy textbooks, single copies of ELT textbooks are now widely available in the market, due to the efficient publicity of multinational publishing enterprises. Most of these are based on a communicative approach. They tend not to have short reading passages, but focus mostly on dialogues illustrating the different communicative functions in the syllabus. However, these textbooks 
provide numerous exercises and practical activities which aim at developing communicative abilities in the learners rather than linguistic knowledge.

Together with the texts and the topics there was the additional element of grammar present in the texts, brought out in a forceful way throughout the units, as stated in the objectives for each lesson. Yet, grammar was not the central focus of the units in the ELT textbooks used in the classrooms in this study, so it was presented in boxes on one side of the page layout, or at the beginning or at the end of a unit. The attention of learners was drawn to these grammar points as 'useful tips to remember'. Although there was not a strong emphasis on grammar in School B as in the lessons in School A, grammar was also a central element in the materials used in the lessons in this school. Other texts used in this class came from a series published at a university in the region, by a team of faculty members and secondary school teachers in their ELT postgraduate programme. This group has already published four books in a series as a response to the deficit of suitable materials for use in classes in this area.

The majority of available textbooks are produced in English speaking countries like the United States, the United Kingdom and Australia. These are mostly oriented to mass distribution without considering the cultural particularities of users and locations. Some of the texts used in the worksheets in these classes were taken from this type of textbook. In School A, the majority of the worksheets that the teachers prepared were based on textbook materials that came predominantly from North America, but also from Britain. This explains the cultural orientation of the different texts and mini- texts used in the classroom activities I observed and recorded.

There was a striking difference in the layout of the worksheets produced by the teachers in each school and the layout of ELT textbooks. The teachers would often photocopy pictures and sets of exercises or questions from other textbooks and then paste them onto a blank sheet of paper to be further photocopied and distributed to the students. Unlike the original books, the worksheets did not have colour pictures and the presentation of the text was different. Teacher B often prepared the handouts herself, and although she included her own drawings in some of them, many of the handouts did not in fact have any pictures.

In the case of Teacher $\mathrm{A}$, he and the group of teachers teaching in grades $10^{\text {th }}$ and $11^{\text {th }}$ selected texts with the grammatical structures that suited the 
level of each grade, but they also selected short reading passages and minitexts or short dialogues. For Teacher B, the major challenge was finding short passages, or paragraphs no more than 10 lines long. In her school, the group of English teachers did not work as a team, but individually, although they met regularly, and had reached an agreement on general guidelines to follow. However, policies were not clearly established, and were not strictly imposed, so she was developing handouts on her own, particularly since she was the only teacher who was focusing on reading ${ }^{3}$. In the two lessons in School B, the teacher had selected texts from ELT textbooks with a clearer orientation to Latin American markets, textbooks that had some relevance to the Colombian context.

\section{Text types and genres}

Not only did the texts in these classes come from various sources, but they also embodied various genres. These included dialogues, brief passages, two or three sentence paragraphs, and even isolated sentences most of them taken from exercises in textbooks. Passages were usually expository texts. I did not find any narrative texts; however, media genres were used in class A. Thus for example, there was a 'weather report', which had been extracted from a textbook. Dialogues were usually photocopied with the corresponding pictures, with the same layout as in the original texts. Teacher B often adapted passages and dialogues and developed the exercise component herself.

In addition, I found that the teachers had incorporated exercises involving multiple choice questions at the end of their worksheets. At the time I carried out the observations, there was increasing pressure on the teachers to prepare students for the ICFES exam, the national entrance examinations required by universities. The ICFES exam had recently been modified to focus on cognitive processes, one of them reading skills, in all subjects in order to test reasoning competencies, to avoid reliance on memorization, a tendency in traditional education in Colombia. As the results of these exams are published in the major national and regional newspapers, schools are competing for the first positions in the league tables showing the exam results. Consequently, the teachers were required to familiarize the students with the format of this type of exam. For this

3 In an interview with the teacher, she commented on the teachers' unwillingness to focus on reading in their classes, due to the difficulties in developing handouts, and the lack of suitable texts. For this reason, they had decided to focus on grammar as they always had done in the past. 
reason, the English teachers had introduced decontextualized multiple choice questions of this type in English at the end of the worksheets.

The type of text incorporated in the worksheets by Teacher A and Teacher $B$ differed. In Class $A$, the teacher used worksheets which he prepared for several units of the syllabus. Teacher B, on the other hand, did not use worksheets like the ones developed by Teacher $\mathrm{A}$ and his colleague, but handouts or photocopies of short passages. These were mini-texts on topics that were familiar to the students and which she had assembled to work on in class.

\section{Topics}

Despite the fact that the PEI had already defined areas of emphasis in each school, a clearly stated policy had not been established in this respect. So, some of the topics reflected in the texts coincided with the school's PEI and some did not. As I explained before, the choice of topics depended more on the availability of texts and on the grammar points in the texts. The fact that the majority of the texts came from different ELT textbooks, especially in class A, explains the wide range of topics, and the lack of connection with the learners' worlds.

\section{Topics in class A}

Many of the texts in the original North American textbooks were, for instance, on topics related to youngsters in the North American context: these included topics such as sports, outdoor activities, summer camps, hobbies, and foods. Several of the texts and exercise activities in Lesson 2 had rather mixed topics that were remote from the worlds familiar to the learners, for instance, exercises and pictures of exotic animals, and countries and cities of the world. Thus one of the oral activities in the Lesson 2 worksheet was based on pictures of exotic foods, which included snails and fish eyes.

Another exercise activity in Lesson 1 in Class A included a picture of a koala, an animal familiar to people in Australia, but certainly not to the majority of students in the class in this study as shown in Extract 1.

\section{Extract 1}

S: 'b'

T: and... ( ) number five...a

S: koala

T: koala...sí 
$5 \mathrm{~S}: \quad$ koala..teacher...qué es un koala teacher?

$\mathrm{T}$ : $\quad$ vamos al quince...quince...look at the picture...and complete the questions then answer them..qué dirá más o menos...

The exchange in Extract 1 took place when the students were doing exercises based on pictures in the worksheet. As the teacher was going over the lesson to correct an error in sentence number 5 in the worksheet, a student took a turn to ask the teacher what a koala bear was however, the teacher ignored the question and, without providing an answer, changed the frame of the activity.

Yet other topics were introduced during the exercise activities in Lesson 1 in Class A. These included: elephants, and a passage about Kenji, an African boy. In lesson 1, Class A, a topic closer to students' lives, 'sports' was introduced. However, this was on 'winter games' and on a particular world champion skier. Again, the topic was quite remote for students in a tropical setting like Colombia. Other sports mentioned were summer sports associated with life in an affluent context in the USA, like sailing, canoeing, and wind surfing.

One of the dialogues in Lesson 1, Class A was about two boys in a summer camp in the USA and the activities that a group of young people had planned. Even the picture illustrating the dialogue showed a log cabin in a national park in the USA. This did not help the students to contextualize the passage or understand the concepts introduced. As Canagarajah notes, 'all textbooks, all teaching materials carry cultural and ideological messages. The pictures, the lifestyles, the stories and the dialogues are full of cultural content; all may potentially be in disaccord with the cultural world of the students' (Canagarajah, 1993. p. 605).

Turns were taken by students on the board, as they volunteered to provide answers and bid for points, a strategy used by the teacher to avoid apathy among the students and encourage their participation. Class interaction was at times disrupted by students' behaviour and chatting. Although the contributions of students and interventions by the teacher increased towards the end of the class, the activities in the worksheet were not completed. Before the class was over, the teacher assigned the remaining activities as homework.

\section{Topics in Class B}

In Class B, on the other hand, a substantial proportion of the readings selected dealt with topics like 'Colombia's natural resources'; 'This is Latin America' 
(focusing on fruits grown in tropical regions); and 'In the Grocery' a text the teacher had prepared herself (on vegetables familiar to the students). These topics were more familiar to the students. There were brief passages, two or three paragraphs long, or as the text 'This is Latin America', three sentence paragraphs. As pointed out before, Teacher B aimed at introducing vocabulary and structures gradually, since these students were reading texts for the first time.

\section{Topics reflecting the PEl emphasis of each school}

A major concern of the teachers, and particularly the English teachers in School A, was the introduction of topics related to the areas of emphasis in the PEI. As indicated earlier, the emphasis of the PEI in School A was natural sciences and a 'school project' La Quebrada Hojasanchas (Hojasanchas Brook), related to environmental pollution around a small brook not far from the school; for this reason, it had been decided by the academic coordinating committee that all subjects in the school curriculum ought to establish thematic links with each other, introducing topics related to these major areas.

The English teachers in School A had decided that they would include questions on Quindio's geographical features and natural resources and major tourist attractions, like theme parks, in the worksheets they prepared for the students. At the time when this study was carried out, they had not yet introduced any reading text on this topic and had only included questions and sentences, and written activities at the end of the worksheets.

In the classes I observed in School B, some of the mini-texts in the worksheets also focused on the two major areas defined in that school's PEI: computers and natural resources. Even though the teacher also had to resort to international ELT textbooks, she had managed to find texts that dealt almost exclusively with these two themes.

\section{Topics related to the students' own lived experience}

In Class B, the worksheet that formed the basis of the lesson 'In the Grocery' as I have mentioned briefly before, had been adapted by the teacher herself. It consisted of a dialogue in which names of fruits and vegetables familiar to the students, like papayas, mangoes, coconuts and potatoes, onions and lettuce, had been introduced instead of those in the dialogue in the source textbook. The dialogue had been adapted from a North American textbook. In one of 
the practical activities, the students were required to infer the names of fruits according to their shape, their qualities, colour and cultural preferences, as shown in Extract 2 below:

\title{
Extract 2
}

\author{
T: una fruta \\ S: $\quad\{$ el limón $\}$ \\ $\mathrm{T}$ : espere un momentico...que a las niñas les gusta.. \\ S: \\ \{la piña\} \\ $5 \mathrm{~T}$ : \\ \{comer...un momentito... \\ que no hemos terminado...comer con sal \\ S: \\ \{mango\} \\ $\mathrm{T}$ : \\ \{sigo.sigo...cuando está verde...cual \\ será esa fruta?\} \\ 10 Ss: mango [several students answer at once] \\ $\mathrm{T}$ : mango..de cuantas palabras es la palabra mango? \\ S: \\ \{apple\} \\ T: bueno...mango se escribe ( ) es completamente transparente.. \\ miren a ver si cabe \\ 15 S: $\{$ sí cabe\} \\ $\mathrm{T}$ : bueno.escríbala \\ S: [one boy speaks up] \{profe.pero a nosotros tambien nos gusta el \\ T: ah.bueno.sí.pero \\ mango dulce \\ S: \\ $\{$ con sal $\}$
}

In this extract, the set of exercises in the worksheet activity consisted of blanks to be filled with the names of fruits familiar to the students, according to clues given in the instructions for each item. In line 1, the teacher's initial prompt was designed to elicit the name of a particular fruit: mango. She then added additional clues: 'que a las niñas les gusta comer con sal' (that girls like to eat with salt). Green mango is a popular fruit among young people. Here, in line 7, we see that a student identified the fruit immediately, after recognising her clues. In line 12 a student interrupts the teacher's turn to offer an answer in English, 'apple', the ony word in English in this extract. In line 17, a student challenged the proposition in the teacher's clue as not totally true, adding that boys also like to eat sweet mango and, in line 19, the student added that they 
like to eat it 'with salt'. The teacher's talk about the text, and the oral activity around the worksheet enabled the students to make sense of the text and to connect it to their lived experience. The teacher led the activity in Spanish too, making the topic even more accessible.

\section{Talk Around The Texts}

Reading aloud: words and sentences, not whole passages

Although reading aloud is a fairly common practice in many language classrooms there was little reading aloud in the four lessons observed in the two schools in this study. There was virtually no reading aloud of reading passages, dialogues, or mini- texts, by the teacher or the students. Only questions, sentences or individual lexical items were read aloud. They were read aloud from the workshop activities, either comprehension questions or sets of exercises in the worksheets.

Class A

In Class A, the teacher read words or sentences in English from the text, to correct errors in the worksheet and to provide explanations or when reformulating in Spanish instructions related to practical activities. In Extract 3 from lesson 1 Class $A$, the teacher started the lesson with corrections of the text, reading aloud the words and sentences.

\section{Extract 3}

$1 \mathrm{~T}: \quad(\quad)$ vamos a corregir...allá dice el número cuatro.colocar ..eating ...have you ever eaten snails? alguna vez ha comido caracol?

And in Extract 4, taken from the same teaching/learning activity, he continued to read from the text, individual lexical items, phrases and sentences, although students also contributed by reading aloud from the text, repeating after the teacher.

\section{Extract 4}

$\mathrm{T}$ : hot dog...pero debajo hay otro que es incorrecto.ahí enseguida dice

S: $\quad$ have you ever...eaten...hot dog?.have you ever eaten\} 


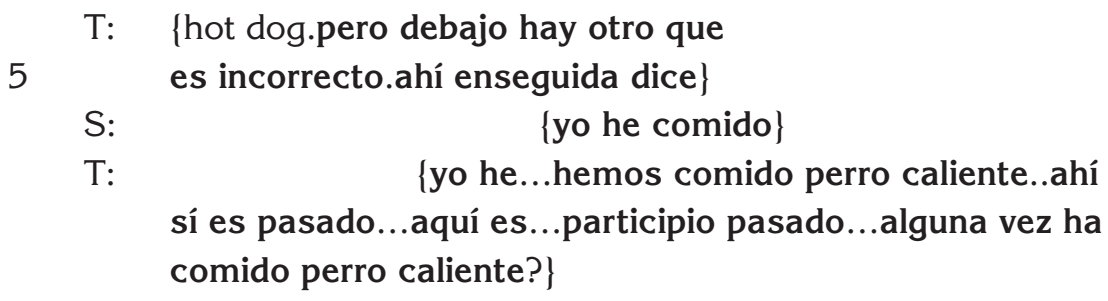

As in other instances in this lesson, both the teacher and the students read from the text, to identify structures or to elicit the meanings of lexical items in Spanish, however the purpose of this was to focus on the grammar of the text, as in this case, to correct an error in the text, 'ate' for 'eaten'. Sometimes, the teacher asked the students to dictate to him the words or sentences that he was going to copy on the board, as in the following extract:

\section{Extract 5}

T: $\quad$ vayan mirando...a ver yo veo..cuantas hay..a ver

S1: todas\}

$\mathrm{T}: \quad$ todas?.la tres $\mathbf{y}$

la cuatro...la cinco..la seis.quien me dicta la primera que hayan

5 identificado?..a ver?..you.ok.number one..ah.entonces vamos a decir algo..vamos a identificar algo.a simplificar.. tenemos..her life hasn't

S1: \{hasn't\}

S: been

In Extract 5, as the interaction took place while the students were at the board, the teacher read part of the sentence that he had asked the students to dictate to him. In line 6 , the teacher read the first part of the sentence in the text, and in lines 7 and 8, two students read the verb, although a student repeated the auxiliary verb the teacher had already read (line 7 ). As in other instances in this lesson, the focus was on grammar and complete sentences were often not read aloud. Students often bid for answers to identify, and read aloud. Extract 6 below shows them bidding to read aloud sentences incorporating the present perfect tense:

\section{Extract 6}

S: la cuarta..la que sigue 
T: la cuarta..tell me? ok. she has

S: she has travelled.she has travelled all over the world

$\mathrm{T}$ : she has travelled.all over the world.she has travelled all over the 5 world

S: she is...esta sí o no?.ha viajado por todo el mundo

S: \{ha recorrido todo el mundo..varios paises\}

T: all over the world..que encuentran acá de especial? She has travelled 10 all over the world...es que los deportistan viajan mucho y conocen

S: \{alrededor del mundo\}

In line 3, after the teacher's prompt, the student read aloud the sentence in the passage, of a text on a world champion skier, and in line 6, he started to read another sentence in English, but then codeswitched into Spanish to read the sentence and, codeswitching again into Spanish. Another student completed the sentence in a slightly different vein. The teacher often elicited the meaning of individual lexical items, as he then does in line 9 interrupting the sentences.

\section{Class $B$}

In lesson 1 , Class $\mathrm{B}$, the teacher started the class asking the learners about their homework, announcing what they were going to do, and then reading, not the text, but the headings in the worksheet, which the students were to write on their worksheets: their name, name of the school, and the date. ${ }^{4}$ She then proceeded to read aloud the 'objectives' of the lesson.

Metalanguage of this kind was frequently used in the printed materials for the students in this class and was often read aloud in this way. This was also done in Class A, but to a lesser extent. The handouts often had the objectives of the lesson in the first line. The objectives for this class were to 'identify the names of fruits in the environment', and 'learn the use of the auxiliary verb 'do'. The teacher also read the two titles in the worksheet: 'Reading' and 'In the Grocery'. She then asked the students to do silent reading of the text (the dialogue) and to identify the known words and underline the unknown words. This activity was to be performed individually. Students seemed a little confused as to what they were supposed to do, although in her directives the teacher

4 According to both teachers, writing the date on the students' worksheets or in their notebooks was important for record-keeping, as students' worksheets were evaluated and given points. 
repeatedly emphasized the presence of 'transparent words' (cognates) in the text, and the need to underline the unknown words so they could check their meaning in the dictionary. Extract 7, shows how the teacher used directives to get the students to read in silence, 'mentalmente', as she started to walk around the room:

\section{Extract 7}

T: ...a ver niño.ya leyó?.tiene que estar leyendo

S: $(\quad)$

$\mathrm{T}$ : no.lea.lea usted.mentalmente.y me va... y a la vez va identificando las palabras que va a buscar en el diccionario...Gómez.. qué hubo...lea

As some students had not started to read and looked a little puzzled as to what they were supposed to do, the teacher started to walk around and help students individually, while at the same time asking the students for their dictionaries. She also helped students select from the different meanings of the words that they had found in their dictionaries and provided grammar explanations both to individual students and to the class as a whole. She also checked on the students' comprehension of the first line of the text and on their ability to recognize what she called 'clear' or 'transparent words' and to underline the words they did not know. Up to this point, the lesson had focused on the first line, a sentence in a dialogue taking place at a grocery shop. The teacher then addressed the class indicating that they could now proceed to read the second line (again, silently to themselves), as shown in Extract 8:

\section{Extract 8}

T: no..have?...no...no se confunda...ahí es ( ) have..tener..organícela..bueno [addressing the class] ya podemos leer el segundo renglón S: $(\quad)$

5 T: uy...claro..el segundo...pero el tercero tambien..es casi todo transparente

S: ( ) [student attempts to read line 2 aloud]

$\mathrm{T}$ : dígame..pero dígame...que todos oigamos...diga

$\mathrm{S}$ : [student tries to read the same line louder] 
Up to this point, and as I have mentioned before, there had been no reading aloud of the text, either by the teacher or the students, except for single words or phrases that both teacher and students were making sense of in Spanish. 'Transparent' words had now become the focus of the lesson since, according to the teacher this was the basic reading strategy that would enable the students to read and understand what they were reading. In line 6 , the teacher's comment to a student reasserted the fact that they were now able to read, since the words in the second and the third line were all 'transparent'.

The lesson turned to the board and students took turns at being given points for turns at the board. The teacher read aloud sentences in Spanish for the students to write in English. There were no other instances of reading aloud in this class. Reading was done mostly to check the meaning of words and phrases in Spanish, with frequent turns by the teacher to elicit the meaning of words as the students read the sentences that had been assigned as homework. This was a recurrent pattern in Lesson 2, as Extract 9 illustrates:

\section{Extract 9}

S: $\quad$ ) [noise]

$\mathrm{T}$ : a ver.oigamos

S: ( ) más de una comida latina...Americana [laughs]

T: aha.latinoamericana.. uh.uh..de la mesa[student looks puzzled.general

5 laughter]

S: de la mesa latinoamericana..ellas ( ) a España [student scratches his head and laughs]

S: ella se origina en latinoamerica..ellas ..ellas fueron a España

$\mathrm{T}$ : sí.fueron

10 S: en 1534

$\mathrm{T}$ : donde aprendieron por primera vez las palabras?

Ss: en América

T: en América.y los españoles las llevaron a España

S: llevadas S:

\{transportadas\}

$\mathrm{T}$ : bueno.miren.[noise] entonces vamos a hacer el ejercicio. vamos a hacer el ejercicio escrito utilizando vocabulario de la hojita que tenemos 
The teacher had asked the students to translate into Spanish the text she had assigned as homework the previous day. In this text, the students were supposed to read a handout, which had mini-texts (short paragraphs under six pictures of fruits and vegetables). In Extract 9, the student who had been nominated, started to read in Spanish word by word, however the teacher elaborated on the student's meaning of the words, according to the normal sequence of modifiers in Spanish, paraphrasing the text that the student had just read (line 6). The teacher also made frequent use of fill-in-the gap questions (line 10) to elicit additional information from the students. After the teacher and the students had contributed to efforts to make meaning out of the text, the lesson turned to the written exercises in the worksheet.

\section{Doing Exercises}

Exercises in these lessons consisted of comprehension questions both in English and in Spanish, as well as other various types of practical activities, i.e. true and false questions, completion of sentences, scrambled sentences and charts and puzzles. As I mentioned before, the teachers themselves often developed the exercises in the worksheets with comprehension questions on the different texts, to prepare students for the universities' national entrance exams, the ICFES exams.

As stated in the objectives written on the first line of the worksheet, after the headings, the main purpose of the English programme was to use the language to communicate in real situations of daily life. However, as the coordinator and the teachers had pointed out on several occasions, the emphasis of the English courses was on reading comprehension and not on oral activities. Questions to check the comprehension of the reading were placed at the end of the activities in the worksheet and were not the priority in the list of contents.

It is interesting to note that in the lessons in School A, although the content of the worksheet followed a basically communicative methodology, in the classes I observed and transcribed, the emphasis was on grammar and writing. The worksheets had practical activities on listening, and speaking for which continuous practice in spoken language and pronunciation was necessary. In the lessons I observed, teachers occasionally took tapes for the students to listen to and the students were also evaluated on their listening skills. Some exercises also asked the students to establish dialogues with their peers and the teacher. However, in none of the classes I observed did I find this type of 
activity being done. Even if the practical activities were all in English in the worksheets, the exercises were often done in both English and Spanish, even after providing the answer in English, comments and further questions on them were carried out in Spanish by both teacher and students.

In Class B, the exercises had been developed by the teacher herself. In contrast with Teacher A's lessons, the students in this class, did not regularly work with worksheets, but with handouts and often with photocopies of short passages or lessons taken out of textbooks and adapted by the teacher.

Exercises in the worksheets in lessons 1 and 2, were basically comprehension questions on the passage or dialogue, choosing the correct answer, giving answers in English to questions in Spanish, true and false activities, and completion type exercises. Although most of the exercises required single lexical items as answers, there were also exercises on the grammar of the text, i.e., identifying the sentences with 'the verb 'to be' and 'changing them into questions and answers'.

\section{The writing practices in the two classrooms}

Accuracy in spelling and in grammar was an important principle in this class. Students' written answers on the board and spelling errors by students at the board were sometimes corrected by pupils themselves, but often by the teacher. It was the teacher who had the authority to erase what was not 'correct'. This principle also governed the writing activities. Accuracy was required on the board, and correct punctuation of the written text was also pointed out to the students, especially in Class B.

In the lessons in Class B, the teacher talk frequently focused on writing, either the writing in the students' worksheets, or in their notebooks or on the board. I have already indicated that students were required to read the text, and underline the unknown words, then copy the meanings in Spanish on top of the words. In the practical activities, students were also required to copy the terms in English and write them in the slots provided or they had to produce complete answers using the sentences extracted from the text that corresponded to the questions at the end of the worksheet.

In both lessons in Class B, students were asked to take turns at the board as part of the evaluation or assessment work the teachers had to do, according to the policy of the school. In Lesson 1, the teacher's talk at the beginning of 
the lesson was mostly focused on the use of the dictionary and on writing. Once the teacher was sure that the students had filled in the blanks in the worksheet, she spent a few minutes going over the heading in the worksheet: 'Reading: In the Grocery', and over the first line of the dialogue, asking students to write the meaning of the words they already knew (lines 2-4), as illustrated in the following extract:

\section{Extract 10}

S: good morning

T: $\quad$ no.esa la saben..en el renglón...no..esa la saben en el renglón..en el renglón uno..despues de punto.dice. good morning madam..la palabra madam quiere decir^$^{\wedge}$ ?

5 Ss: $\{$ señora $\}$

T: escríbala ahí [teacher addressing a student while she walks around]

S: arribita?

T: [sí [to the class.raising tone of voice] lo otro.ya van a

10 empezar a buscar en el diccionario lo que no conozcan\}

S: $\quad$ primero buscamos los qué $\}$

$\mathrm{T}$ : no.primero tienen que leer completo todo el párrafo e ir subrayando las que vamos a buscar en el diccionario. entonces empecemos...

15 hay muchas transparentes.hmm^^.qué hubo pues. lea

This was an activity that was still relatively unfamiliar to the students. Some students seemed confused about locating the paragraphs in the worksheet where they had to write the Spanish translation of the words. As I have already indicated, reading in this lesson had the purpose of underlining the unknown words, finding their meaning in the dictionary, and writing the meaning in Spanish over the English words (lines 8-10), in these activities accuracy was higlighted as Extract 11 shows:

\section{Extract 11}

T: la palabra naranja^

S: $\quad$ \{orange\}[several students at once]

$\mathrm{T}$ : $\quad$ tambien la saben...como estamos hablando de naranjas en plural.recuerden escribirla en plural 
5

S: $\quad\{(\quad)\}$

T: $\quad$ le agregamos

la 's'..y por favor cómo es?

Ss: $\quad$ \{please

$\mathrm{T}$ : $\quad$ \{please.pero recuerden

10 como se escribe ${ }^{\wedge}$

Ss: please [Spanish pronunciation]

T: $\quad$ ah.bueno..se dice please pero se escribe please [Spanish pronunciation][addressing a student] pero usted no ha hecho nada...porqué?...muestre a ver.. bueno..hasta aquí va signo de interrogación aquí...muéstreme el diccionario

In the above extract, the teacher was drawing on the students' previous knowledge. She pointed out that the word 'orange' had to be written down in its plural form (lines 3-8). The correct spelling of words that caused difficulty to Spanish speakers was also underlined. The teacher asked for the meaning of 'please' and the spelling of the word (lines 6-13) again, drawing on the students' previous knowledge, pronouncing the English word as if it were a Spanish word (lines 13-14). In lines 15-17, the teacher corrected the spelling of the pronoun 'it' that a student had spelled as 'ti' and also pointed out the question mark he had omitted. Punctuation was often brought to the students' attention both in the reading of the text and in the writing activities.

\section{The monolingualism of the written work in the class}

As I have shown in the previous section, the written exercises in the worksheets and the notebooks were all in English, the language of writing in both classes. With the exception of Lesson 1, in Class B where the meanings of lexical items had to be written in Spanish over the English words, nearly all the in-class writing in these classes was in English. Some homework for Teacher B also involved translation. Otherwise, the items in the exercises in the worksheet were supposed to be written in English even when the instructions were in Spanish. At the board, the language of writing was also English. Students in these classes had a tacit understanding that when they went to the board they were to write in English. Some of them had to make use of all of the resources available to them (including reliance on help from others) in order to write in 
English on the board and solve the difficulties that they encountered. Being at the board, put the students 'on stage' (Goffman, 1956, 1974 Arthur, 2001) although having the worksheet with them put less pressure on them.

\section{Conclusions}

Literacy practices in both classes played an important role in the distribution of turns and allowed learners to engage in collaborative work while at the board or while answering the teacher's questions. However, very few meaningful episodes of real communication in English were observed in these lessons. Reading in these classes is an activity focused on vocabulary, translation and grammar.

Teachers such as the two I have focused on in this study fall back on their own beliefs and personal experiences to comply with the demands of the syllabus and the curriculum. The Curricular Guidelines for Foreign Languages (MEN, 1999), do not indicate that an emphasis on 'reading comprehension' should be part of the methodological orientations teachers should follow, and instead give them freedom to decide on the approaches to be used. However, in the lessons I transcribed and in others that I observed but did not transcribe, special importance is granted to reading. It is still the main skill emphasised in the lessons. Teachers and even academic coordinators consider that students need to develop this skill for instrumental purposes in higher education, and especially for passing the ICFES exam, which test among other competences, reading in all areas of the curriculum.

The data analysis of the four lessons revealed that students learn to read words and phrases identifying grammar structures and translating lexical items. Teachers selected topics they thought would motivate the students' interest. However, reading is another of the requirements in the syllabus and students' concern is mostly with grades or marks, rather than with reading as a pleasurable activity.

Both Teacher A and Teacher B had their own ways of 'doing reading'. As I have shown, in these classes, reading was an activity designed to facilitate acquisition of knowledge of grammar and vocabulary; while translation was used to make sense of texts and to facilitate comprehension. The 1982 English Syllabus (MEN, 1982) intended to function as a transition between traditional pedagogies in English teaching/learning practices in Colombia, and the 
approaches focusing on communicative competence, popular at the time. It considered 'reading' to be different from translation. The distinction between the two terms is still not clear in pedagogic debates and in actual classroom practice, as I have shown here. A significant number of teachers continue to 'do translation', despite the fact that 'translation' is not regarded as an appropriate dimension of ELT practice.

Texts in schools such as those in this study are selected according to the teachers' own criteria and to the availability of the texts. No clear policies exist regarding the selection and use of texts. Although the adoption of a textbook is discouraged in public schools due to their high cost, a wide range of recently published materials and textbooks are available commercially. However, these are not easily afforded by the students and the teachers in public schools, besides, the imported textbooks are in the majority of cases not appropriate for the teachers' and the schools' pedagogical orientations and ways of teaching. Regardless of their cultural content, the choice of texts in these schools was often determined by the length of the passages or dialogues (they generally have to be very short) or by the grammar content.

From my interviews with the two teachers, I learned that a complex process was involved in the construction and re-construction of texts from the initial selection that teachers made. Texts were usually photocopied from other textbooks and adapted by the teachers themselves. A new layout and content resulted as they adjusted these new texts according to the requirements of the syllabus and their own purposes. Sets of questions about the topics incorporated in the schools' PEI were also included, as well as other types of class activities. As a result, texts characterised by different genres were pasted onto the worksheets. And in addition, the texts also reflected very different approaches to ELT practice. Teachers used their own resources, experience and ideas in the creation of these new texts producing materials suitable for their working conditions.

These re-constructed texts were used over several weeks or even months; others were used for shorter periods (e.g. Class B). Texts were either read aloud by the teacher, either to do the homework in class, as in Class A, or to evaluate the homework previously assigned as in Class B, or to write other texts on the board or in the students' notebooks. Teachers usually read aloud words, phrases or sentences in English from the texts pointing out the grammar 
or the meaning of the words. Teacher B used the concept of 'cognate words' (palabras transparentes) as a way to facilitate reading in English, because her students were in the $8^{\text {th }}$ grade and were starting to learn English.

Several of the topics in the texts in the worksheets and handouts in the lessons I studied were 'global' in nature, especially in Class A, where texts were often extracted from North American publications with a clear cultural orientation to North American middle-class values and way of life. In contrast, in Class B, texts were re-designed by the teacher so that they could be more familiar to the students and linked more closely with their life worlds. It could be said that this teacher was 'localising' texts originating from the global publishing industry. Thus, the processes of selection, construction and use of texts were not mere reflections of global pressures. The teachers' textual and pedagogical practices were more complex and varied than this. Sometimes their practice reflected global pressures but sometimes they were consciously localised. Moreover, they attended to the needs to meet local language policy developments and the particular local conditions in schools.

Many students feel that success in English language learning is only achieved outside the realm of the public school. The ideas that teachers have about the possibility of learning English in public school contexts, are equally pessimistic. There are few resources and difficult working conditions, and the way teachers position the learners also has a direct effect on the attitude of the students; however, teachers, such as those in this case study, do manage to comply with the syllabus and the policy demands and accomplish language lessons.

Teachers' talk with texts and about the texts appeared to be a means of coping with large class sizes and the general exhuberance of the students. The classroom routines were also a means of dealing with the continual imposition of new aspects of language education policy in these schools. To use Arthur's (2001) words, 'the constraining framework of institutionalized and institutionalizing pressures' (p. 73) may well have been hindering more meaningful and congruent learning taking place in these contexts.

To conclude, there is a pressing need in the ELT field in Colombia for empirical studies on the teaching learning context in public schools, especially on the process of day to day interaction in the classroom, the talk of teachers and learners and the pedagogical practices taking place around texts. Few 
reports are published on these issues in the micro context of the classroom and those in the wider policy context. There needs to be more awareness of the scope of the need for teacher education and support in the ELT field in Colombia, and the need to provide teachers in public schools with opportunities to reflect on the immediate teaching/learning context in their schools and on their relation with the wider policy context.

\section{Transcription conventions}

Font:

Bold:

Normal font:

$\mathrm{T}$ :

S:

Ss:

S1, S2, S3:

( ):

[ ]:

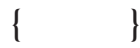

$\{()\}$

(.)

-..:

n.......:

?

$\wedge$
Times New Roman

\section{Spanish}

English

Teacher

Student

more than one student speaking

Individual students

inaudible speech

comments about nonverbal behaviour

overlapping speech

overlapping speech. Inaudible

pause of less than one second

short pause

long pause

question

rising intonation

\section{References}

Allwright, R. L. (1997) "Classroom-oriented research in second language learning". Encyclopedia of Language and Education. Vol. 4. pp: 63-64. Hornberger, N. and Corson, D. (eds.). Dordrecht: Kluwer Academic Publishers.

Arthur, J. (2001) Codeswitching and collusion: classroom interaction in Botswana primary schools. In Heller, M. and Martin-Jones, M. (eds). Voices of Authority. Westport: Ablex Publishing.

Auerbach, E. (2000) "Creating Participatory Learning Communities". In Kelly, H.J. and Eggington, W.G. (eds.), The Sociopolitics of English Language Teaching. 143-164.

Barton, D. (1994) Literacy: An Introduction to the Ecology of Written Language. Oxford: Blackwell 
Canagarajah, A.S. (1993) "Critical ethnography of a Sri Lankan classroom: Ambiguities in student opposition to reproduction through ESOL”. TESOL Quarterly 27 (4), 601-626.

Davis, K. (1992) "Validity and reliability in qualitative research on second language acquisition and teaching: Another researcher comments....TESOL Quarterly, 26, 605-608.

De Castell, S. and Luke, A. (1987) “Literacy Instruction: Technology and Technique”. American Journal of Education. May, 413-40.

Dendrinos, B. (1992) The EFL Textbook and Ideology. Athens: N.G. Grivas publications.

Ellis, D. (1990) Cross-cultural relevance in EFL materials production with special reference to Muslim culture, paper presented at AILA '90.

Erickson, F. (1990) "Handbook of Research on Teaching". Third Edition. Wittrock (ed.). London: Collier Macmillan Publishers.

Gee, J. P. (1990) "Sociolinguistics and Literacies: Ideologies in Discourses": London: Taylor and Francis.

Gee, J. P. (2000) Teenagers in new times: a new literacy studies perspective. Journal of Adolescence \& Adult Literacy. 43.5: 412-20.

Goffman, E. (1956) The presentation of Self in Everyday Life. New York: Doubleday.

Goffman, E. (1974) Frame Analysis. Harmondsworth: Penguin.

Heath, S. B. (1983) Ways with Words: Language, Life, and Work in Communities and Classrooms. Cambridge: Cambridge University Press.

Luke, C., de Castell, S. and Luke, A. (1989) "Beyond Criticism: The authority of the school text”. In S. de Castell, A. Luke and C. Luke (eds) Language Authority and Criticism: Readings on the School Textbook. London: The Falmer Press.

Martin-Jones, M. and Jones, K. (2000) Multiligual Literacies, Amsterdam/Philadelphia. John Benjamins Publishing Co.

Ministerio de Educación Nacional. (1982) Programa de Inglés. Bogotá Editorial Norma.

Ministerio de Educación Nacional. (1994) Ley General de Educación. Bogotá. Editorial MEN.

Ministerio de Educación Nacional. (1997) Proyecto Educativo Institucional (PEI). Bogotá. Editorial MEN

Ministerio de Educación Nacional. (1998) Lineamientos Curriculares: Indicadores de Logros Curriculares. (Resolución 2343 de junio 5 de 1996) Bogotá: Editorial MEN.

Ministerio de Educación Nacional. (1999) Lineamientos Curriculares: Idiomas Extranjeros. Bogotá: Editorial MEN.

Ministerio de Educación Nacional. (2000) La Revolución Educativa. Plan Sectorial 2002-2006. Bogotá. Editorial MEN.

Norton Pierce, B. (1995) "Social identity, investment and language learning". TESOL Quarterly 29, 9-31. 
Pennycook, A. (1994) The Cultural Politics of English as an International Language. London: Longman.

Prodromou, L. (1988) "English as cultural action”. ELT Journal 42 (2): 73-83.

Street, B. (1984) Literacy in Theory and Practice. Cambridge: Cambridge University Press

Street, B. (Ed.) (1993) Cross-cultural Approaches to Literacy. Cambridge: Cambridge University Press.

THE AUTHOR

Silvia Valencia Giraldo holds a Ph.D. in Education, area: Bilingualism, from University of Wales, Aberystwyth, UK; M.A. in Linguistics, Lancaster University, Lancaster, UK; B.A in Liberal Arts, Indiana University of Pennsylvania, Indiana, Pa, USA.

E-mail: silvia_valencia@hotmail.com 